\title{
Current directions in LD powertrain technology in response to stringent exhaust emissions and fuel efficiency requirements
}

\begin{abstract}
The major global automotive markets have all set limits for exhaust emissions from new road vehicles, which have become increasingly stringent over the past few decades. There is also considerable pressure to reduce fuel consumption and $\mathrm{CO}_{2}$ emissions - around $80 \%$ of all new passenger cars sold globally are subject to some kind of energy efficiency regulation. Such legal requirements necessitate extensive $R \& D$ and testing and the entire field is undergoing a period of rapid change. Despite a recent trend towards harmonisation, at present significant regional differences exist, which vary from the analytical laboratory methods specified, the list of regulated pollutants, the numerical values of the emissions limits and the test cycles employed for engine and chassis dynamometer testing of vehicles and their powertrains. Here the key points are reviewed and strategies and technologies employed to deal with these emissions challenges are discussed. Incoming automotive emissions regulations including the WLTP and Real Driving Emissions are discussed and in conclusion likely directions in powertrain technology are identified.
\end{abstract}

Key words: LD engines, powertrain technology, exhaust emissions, emissions standards, WLTP, RDE

\section{Introduction}

Notwithstanding decades of improvement in the industry, concern over the impact of vehicles on air quality remains high. Emissions of greenhouse gases from road vehicles remain very high on the political agenda; emissions of particulate matter are coming under increasing scrutiny as a form of pollution with wide-ranging negative impacts; concern over $\mathrm{NO}_{\mathrm{x}}$ emissions is very high; certain as-yet unregulated gaseous emissions are potential air quality risks. Looking to the longer term, the security of the oil supply and broader energy usage concerns have become very much part of the automotive development landscape.

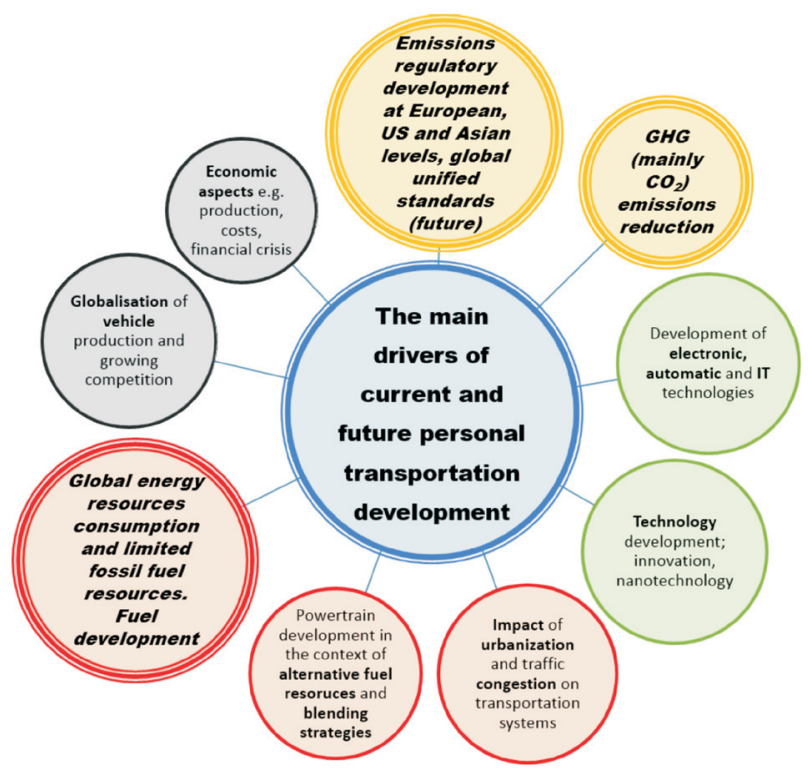

Fig. 1. Main drivers of powertrain development [9]

Concern over gaseous and solid pollutants - perhaps most infamously $\mathrm{CO}_{2}$ - has become a concern for all major global markets, not just the United States and European Union. Among the main drivers that influence vehicle technology and powertrain development are emissions regulatory development in the EU, USA and Asia (mainly Japan, China, India), GHG (mainly $\mathrm{CO}_{2}$ ) emissions reduction which is aligned with fuel consumption/fuel economy (FC/FE) and has an influence on consumption of energy resources (Fig. 1) [9].

The response to this has been the introduction of various pieces of legislation, some imposing increasingly strict emissions limits; others various mandates, incentives and quotas regarding fuel consumption and the types of fuels used. Now, following revelations that emissions from real vehicle usage are generally poorly reproduced in the laboratory, test methods themselves are changing: first in the laboratory (e.g. the WLTP/C - GTR15; USA CFR 1065/1066 procedures); furthermore, real driving emissions have increased in importance to the point where RDE/ PEMS measurements are now a legal requirement in the EU (although so far only for monitoring purposes). Randomised laboratory test cycles, once considered a viable approach for particle number measurements, now look very unlikely to be implemented in view of progress with PN PEMS.

The introduction of particle number limits and increased scrutiny of particulate emissions from engine types other than Diesel represents a somewhat new and challenging direction in emissions testing and control. These factors exert massive pressure on vehicle and engine manufacturers (both light duty and heavy duty), their suppliers and the oil and fuel industries. Reduction of harmful emissions, today especially $\mathrm{NO}_{\mathrm{x}}$ for diesel LD engines and PN for gasoline DI engines are among the main drivers influencing personal transport development (Fig. 1). Other, allied fields such as R\&D and fuel additive and lubricant suppliers also find themselves subject to the same forces. Many of the afore mentioned problems are shared by the various strands of the industry - passenger car and light commercial vehicle/heavy duty/ 
off road/marine - and many of the proposed strategies and technical solutions have multi-segment applicability.

However, the market is dictated not only by political and technical factors, but also by consumer demands, which themselves also evolve. Something both legislators and the general public have in common is the goal of reducing fuel consumption, without any sacrifices in terms of durability or safety. Responding to this pressure, a broad range of advanced engine technologies, catalytic aftertreatment systems, revised fuel types, bespoke lubricants and friction inhibitors, etc. have been introduced. These strategies are often interrelated: low sulphur fuel is required for aftertreatment system compatibility; advanced engine design has impacts on required lubricant properties, etc. Fundamental changes to the propulsion strategy for on-road vehicles (e.g. fuel types/the implementation of advanced electromechanical systems - hybrids) represent a revolution in the industry. All these advanced technologies must be developed, tested, approved and certified. As explained in later sections of this paper, recent changes mean that these processes are no longer confined to the laboratory.

\section{Development of global emissions rules}

\subsection{General approaches of modern emission standards}

After about 50 years of vehicular emissions regulation and control, today there are many different emissions standards, test procedures and limits mandated in the main automotive markets such as the EU, USA, Asia (mainly Japan, China and India), Brazil and other countries (Fig. 3). Emissions standards are built on four pillars: tailpipe limits for harmful pollutants, test procedures that describe the test methodology, the driving cycle used on a chassis dynamom- eter in emissions laboratory in prescribed test conditions, equations describing the calculation of test results, including corrections for temperature and humidity (inter alia) and weighting factors (in certain cases) $[1,12,17,26]$.

1947: California passes the Air Pollution Control Act (no limits for vehicles yet)
1966: California sets limits for $\mathrm{HC}$ and CO emissions from vehicles
1970: US Congress passes the Clean Air Act, initially requiring a 90\% reduction is emissions in
5 years (later changed to 8 years); EEC first defines emissions limits and test procedure in
90/69/EEC
1970: first European regulation - Directive 70/220/EEC
1971: evaporative emissions limited for the first time in the USA
1975: first generation catalytic converters introduced in the USA; unleaded petrol
introduced; fuel sulphur content limited in the EU for the first time
1976: three-way catalysts used in California for the first time
1977: Vehicular NO, emissions limited in the USA for the first time
1981: Clean Air Act amended; in the USA new cars now feature three-way catalysts,
with $\mathrm{O}_{2}$ sensors and computer control in most cases
1985: Diesel emissions standards established in the USA
1987: leaded petrol banned in the EU
1988: Euro 0 standard introduced
Early 1990s: Diesel sulphur content reduced to help with efforts to meet new emissions
standards
Early 1990s: Emissions limits lowered, oxygenated fuel introduced
1993: EU test procedure changed (New European Driving Cycle), amended again 7 years later
1993-2009: EU sets and amends limits to control petrol and Diesel fuel quality and reduce
emissions
1990s-2015: Euro 1 to Euro 6 standards introduced

Fig. 2. Milestones in emissions regulation and emissions control [9]

Global harmonization of automotive emissions regulations remains a distant prospect, but it is now often mentioned that harmonization of emissions procedure and protocols could bring benefits for automotive OEMs and customers - customers today are not getting value from region-to-region variation [26]. The first step in this direction could be UNECE GRPE programme on the introduction of World Light-duty Vehicles (harmonized) Test Procedure WLTP that was carried out over 2007-2015 (for

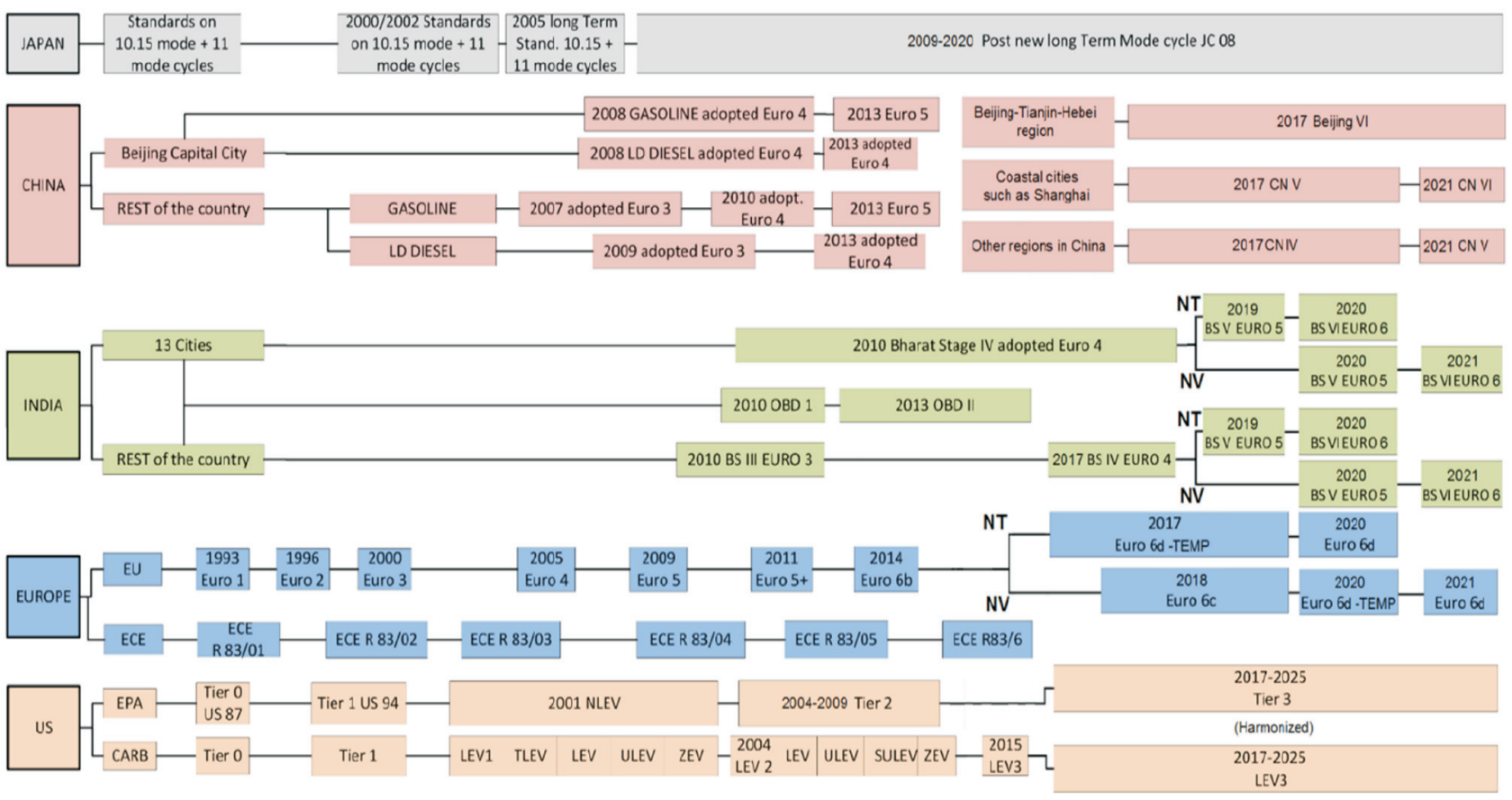

Fig. 3. Development trends in emissions regulation on the main automotive markets 


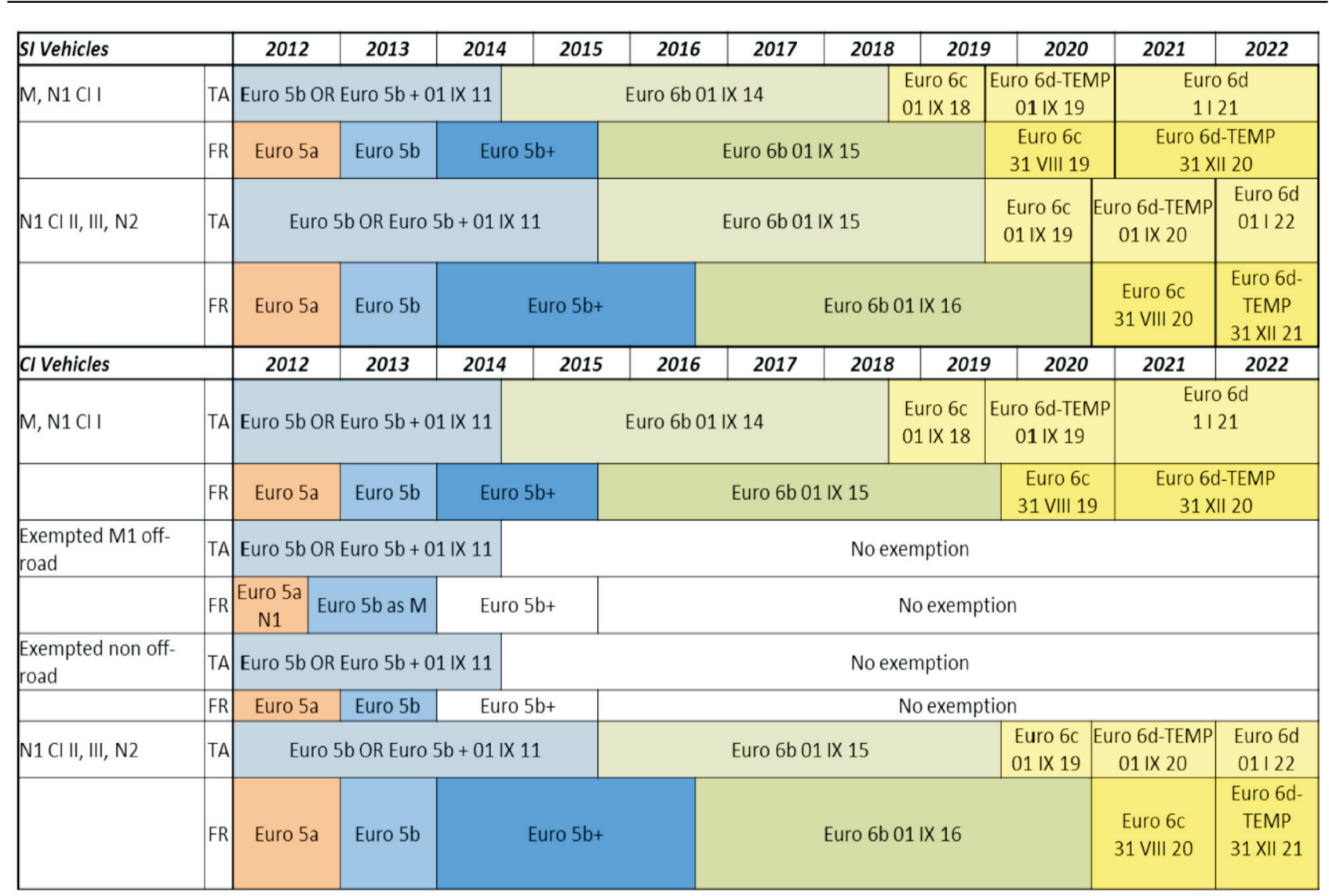

Fig. 4. Emissions reduction path in European Union countries

${ }^{*}$ WLTP, earliest expected application in Europe: September 2017. ${ }^{* *}$ RDE, Euro 6c without quantitative RDE requirements, Full RDE test is applied at Euro 6d

the first step) by the EU, Japan, India, China, and Korea, with the support of other countries, (including the USA) and finalized via a new UNECE emissions regulation (GTR15, published in 2014) which defines the test procedure based around the WLTC.

Test cycle and a technical specification; in line with a "split level approach" [12], limits will be set during the transposition to national legislation in the EU and some Asian countries.

\subsection{European Union}

The new framework for vehicle type-approval proposed by the European Commission would harmonise enforcement practices across EU member states and shift the focus from pre-production to in-service conformity and market surveillance [14].

The emissions reduction pathway in the EU, with phasein dates for new emissions limits Euro 6c, Euro6d-Temp and Euro 6d are presented in Fig. 4. The latest emissions standards were presented in the Commission Regulation (EU) 2016/646 of 20 April 2016 amending Regulation (EC) No 692/2008. The main issues for Euro 6 regulations are the following:

Euro $6 c-F u l l$ Euro 6 emission requirements but without quantitative RDE requirements, i.e. Euro 6 b emission standard, final particle number standards for PI vehicles, use of E10 and B7 reference fuel (where applicable), assessed on the regulatory laboratory test cycle, with RDE testing for monitoring only (no NTE emission limits applied);

Euro 6d-TEMP - Full Euro 6 emission requirements, i.e. Euro $6 \mathrm{~b}$ emission standard, final particle number standards for PI vehicles, use of E10 and B7 reference fuel (where applicable), assessed on the regulatory laboratory test cycle, with RDE testing with NTE limits based on temporary conformity factors;

Euro 6d - Full Euro 6 emission requirements, i.e. Euro $6 \mathrm{~b}$ emission standard, final particle number standards for PI vehicles, use of E10 and B7 reference fuel (where applicable), assessed on the regulatory laboratory test cycle, with RDE testing with NTE limits based on final conformity factors.

\subsection{USA (including California)}

In general it can be stated that California is the "home" of exhaust emissions legislation and control, with the Californian approach continuing to influence the rest of the US and the rest of the world. As early as 2007 fourteen US states other than California had implemented Californian legislation, at least in part. But in the United States, the Environmental Protection Agency (EPA) has the statutory authority under the Clean Air Act (CAA) to regulate greenhouse gas (GHG) emissions.

In 2012, the EPA, in coordination with the National Highway Safety Administration (NHTSA) and the California 
Air Resources Board (CARB) issued a Final Rulemaking (FRM) for Light-duty Vehicle Greenhouse Gas Emissions. In this FRM, the EPA set tailpipe emission standards for all light-duty vehicles from 2017 MY (Model Year) through 2025 MY. The regulation also tightens sulphur limits for gasoline. Both the certification limits (Bins) and the fleet average standards are expressed using the sum of NMOG $+\mathrm{NO}_{\mathrm{x}}$ emissions (Fig. 5). The required emission durability has been increased to 150,000 miles or 15 years, whichever comes first. Gasoline vehicles are tested - for exhaust and evaporative emissions - using gasoline containing $10 \%$ ethanol (E10) [11].

\begin{tabular}{|c|c|c|c|c|}
\hline Bin & $\mathrm{NMOG}+\mathrm{NOx}[\mathrm{mg} / \mathrm{mi}]$ & $P M^{11}[\mathrm{mg} / \mathrm{mi}]$ & $\mathrm{CO}[\mathrm{g} / \mathrm{mi}]$ & $\mathrm{HCHO}[\mathrm{mg} / \mathrm{mi}]$ \\
\hline Bin 160 & 160 & 3 & 4,2 & 4 \\
\hline Bin 125 & 125 & 3 & 2,1 & 4 \\
\hline Bin 70 & 70 & 3 & 1,7 & 4 \\
\hline Bin 50 & 50 & 3 & 1,7 & 4 \\
\hline Bin 30 & 30 & 3 & 1,0 & 4 \\
\hline Bin 20 & 20 & 3 & 1,0 & 4 \\
\hline $\operatorname{Bin} 0$ & 0 & 0 & 0 & 0 \\
\hline
\end{tabular}

Fig. 5. US federal exhaust emissions standards [11]

There was also a general concerns about setting standards so far into the future, that were mainly focused on the development of technology by automotive OEMs and consumer acceptance of this new technologies. To support automotive OEMs, the EPA formally adopted in its regulations a Midterm Evaluation (MTE) which has been designed to assess only the feasibility of the 2022 MY to 2025 MY standards. The standards from 2017 MY to 2021 MY already fixed and cannot be changed [25].

California applied emissions standards called LEV. LEV III standards were finalized December 2012 with phase-in 2015-25. Beginning 2020 all vehicles need to be certified to LEV III (Fig. 6).

\begin{tabular}{|c|c|c|c|c|c|}
\hline \multicolumn{6}{|c|}{$\begin{array}{l}\text { LEV III FTP STANDARDS } \\
\text { Passenger Cars and Light Duty Trucks } \leq 8.500 \mathrm{lbs}\end{array}$} \\
\hline $\begin{array}{l}\text { Durability } \\
\text { Vehicle } \\
\text { Basis (mi) }\end{array}$ & $\begin{array}{l}\text { Vehicle } \\
\text { Emission } \\
\text { Category" }\end{array}$ & $\begin{array}{l}\text { NMOG+ } \\
\text { NOx } \\
(\mathrm{g} / \mathrm{mi})\end{array}$ & $\underset{(g / m i)}{C O}$ & $\begin{array}{l}\text { Formaldehyde } \\
\text { (mg/mi) }\end{array}$ & $\begin{array}{l}\text { Particulates }{ }^{2)} \\
\qquad(\mathrm{g} / \mathrm{mi})\end{array}$ \\
\hline \multirow{6}{*}{$\begin{array}{l}150.000 \\
\text { (optional) }\end{array}$} & LEV160 & 0,160 & 4,2 & 4 & 0,01 \\
\hline & ULEV125 & 0,125 & 2,1 & 4 & 0,01 \\
\hline & ULEV70 & 0,070 & 1,7 & 4 & 0,01 \\
\hline & ULEV50 & 0,050 & 1,7 & 4 & 0,01 \\
\hline & SULEV30 & 0,030 & 1,0 & 4 & 0,01 \\
\hline & SULEV 20 & 0,020 & 1,0 & 4 & 0,01 \\
\hline
\end{tabular}

Fig. 6. California LEV standards [11]

\subsection{China, India and Japan}

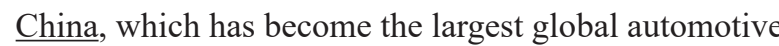
market, has introduced a very ambitious emissions reduction programme since 2013 that has lead to significant reductions in automotive emissions, especially in large urban agglomerations, by introducing rules similar to Euro 4, 5 and 6, introducing also WLTP rules and even Californian LEV III standards in Beijing (Fig. 3) [34].

India is following the EU emissions reduction programme via the introduction of BS IV (Bharat Stage 4), BS
V and BS VI rules (which are similar to Euro 4, Euro 5 and Euro 6), with an intermediate phase between BS V and VI as short as possible (Fig. 3)

Japan has its own emissions regulation named "Post new long term regulation" and its own Japanese test cycle - JC 08, which replaced the old Mode 10.15 and Mode 11 test cycles (Fig. 3). Japan is also very active at the UN ECE GRPE informal group that is developing the new WLTP test procedure with the intention to implement the WLTC test cycle and the entire WLTP procedure in Japanese emissions regulation. (As Japanese traffic and speed limits do not permit the high speeds typical of European/North American motorways, the Extra High phase of the WLTC will not be used for testing in Japan.)

\section{Development of emissions test methods}

\subsection{New light duty world harmonized test procedure - WLTP}

In November 2007 the World Forum for Harmonization of Vehicles Regulations (WP.29) of the UNECE on GRPE session established an informal group to prepare a road map for the development of a World-harmonized light-duty vehicle test procedure (WLTP). The development of the WLTP comprised two main elements:

- Development of a harmonized driving cycle representative of world average driving conditions (internally referred to as the DHC - Informal Subgroup on the Development of the WLTP Test Cycle - see Fig. 7)

- Development of a harmonized test procedure that sets the conditions, requirements, tolerances, etc. for the emissions test, test equipment and instruments (internally referred to as the DTP - Informal Subgroup on the Development of the WLTP Test Procedure)
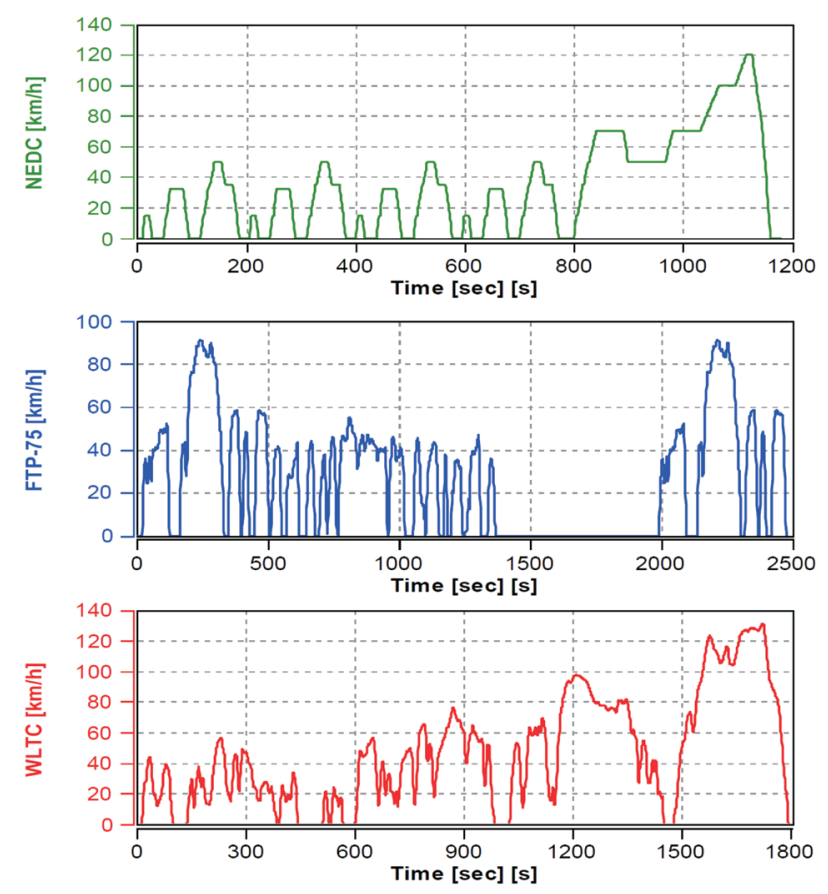

Fig. 7. The WLTC driving cycle in comparison to the NEDC and FTP-75 
At its November 2007 session, WP.29 decided to set up an informal WLTP group under GRPE to prepare a roadmap for the development of the WLTP. After various meetings and intense discussions, WLTP informal group presented in June 2009 a first road map consisting of 3 phases.

(a) Phase 1 (2009-2014): development of the worldwide harmonised light duty driving cycle and associated test procedure for the common measurement of criteria compounds, $\mathrm{CO}_{2}$, fuel and energy consumption (Type 1 test of EU type approval procedure).

(b) Phase 2 (2014-2018): low temperature/high altitude test procedure, durability, in-service conformity, technical requirements for on-board diagnostics (OBD), mobile airconditioning (MAC) system energy efficiency, off-cycle/real driving emissions.

(c) Phase 3 (2018+): emission limit values and OBD threshold limits, definition of reference fuels, comparison with regional requirements.

The term 'WLTP' has been in use for some years, but very recent developments and formalisations in the development of this programme mean that it in fact it is use only as unofficial name. GTR 15 ('Global Technical Regulation No. 15') has come into being and so 'GTR 15 ' is now a more appropriate term for developments and planned implementations in this area. The main planned target is regarding $\mathrm{CO}_{2}$ emissions and fuel consumption, since at the Euro 6 level emissions limits for regulated pollutants are not cycle-specific and there is no political mandate to change emissions limits to "match" the test cycle - a significant consideration (see Fig. 8).

EU institutions are currently working on transposition and implementation of WLTP regulation from UN ECE GTR 15 to European legislation. In the EU the WLTP is being prepared as a new implementing and amending regulation of co-decision EC No. 715/2007 that will eventually replace EC No. 692/2008 (NEDC), the well-known regulation currently used. The WLTP will be introduced via a new implementing Regulation 201a/xxx (after finishing all steps of acceptance procedure and possible changes in European Union institution), which is planned to replace Regulation (EC) 692/2008. This new Regulation 201a/xxx will also change the emission type definition for vehicles in this way that any first time official emissions testing of vehicles for the WLTP inevitably creates new emission type approvals (TA), regardless of whether the vehicles have already a previous emission type approval according to the implementing provisions of Regulation (EC) $692 / 2008$ or not [28].

This means that vehicles type approved to the WLTP after 1 September 2017 will have to comply with RDE requirements (PEMS testing), with step 1 not-to-exceed (NTE) emission limits. Since type approval to the WLTP is mandatory for all new vehicles as from 1 September 2018, all vehicles not fulfilling the RDE step 1 requirements would have to be tested for the WLTP before 1 September 2017 or could not be sold anymore after 1 September 2018.

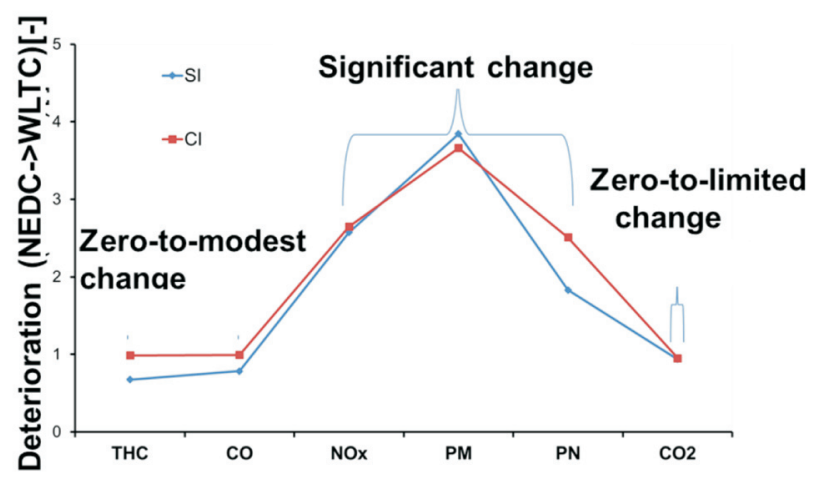

Fig. 8. Emissions over the WLTC compared to the NEDC for a pool of European SI and CI vehicles [8]

The new test cycle WLTC (World Light-duty Test Cycle) that will be introduced in WLTP regulation and is already specified in GTR15 is very different from the current NEDC cycle as it is more transient and somewhat similar to the US FPT 75 cycle. However, various factors determine the fuel consumed over a driving cycle, of which the cycle itself is but one factor. For pollutants other than $\mathrm{CO}_{2}$ the picture is even more complex (Fig. 8). As a basic starting point, it is helpful to compare different cycles' speed traces by eye. Figure shows the speed traces for the NEDC, FTP-75 and WLTC test cycles. (Note that the three traces do not have common $x$ axes.) Note also that for the FTP-75 the long period of vehicle standstill (ending at around 2000 seconds) is not idling, but engine shutoff ("hot soak"), during which exhaust gas is not sampled. The FTP-75 is the cycle with the longest history - automotive emissions legislation and prescribed test methods have a long history. The need to have stable test conditions and for results to be reproducible in any properly-equipped laboratory was considered a strong enough argument for automotive emissions legislation to only apply in laboratory contexts. However laboratory test cycles are not enough in achieving the general goals of reducing harmful emissions and fuel/energy consumption. Because the current test procedure, based on the NEDC cycle run under laboratory conditions, in outdated and there can be large (even huge) discrepancies between laboratory test results and real world emissions, a new WLTP methodology requires many modifications in the emission test procedure as well as in the emission testing laboratory (Fig. 9). The most important of them are $[5,12,27]$ :

Related to the test cycle:

- WLTC (Worldwide harmonized Light duty Test Cycle)

- Different for 4 vehicle classes, depending on the power/ weight ratio and max. speed

- More dynamic, less idling, longer $(20 \rightarrow 30 \mathrm{~min})$, higher average speed $(34 \rightarrow 46 \mathrm{~km} / \mathrm{h})$. and higher max speed $(120 \rightarrow 131 \mathrm{~km} / \mathrm{h})$.

- Individual shifting points for each vehicle with a manual transmission.

Related to road load simulation for testing

- More realistic road load determination and simulation, to eliminate fuel consumption optimization. 




Fig. 9. BOSMAL - New Euro 6c/6d emission testing laboratory that meets WLTP/GTR15 testing requirements

- Test of a "Low $\mathrm{CO}_{2}$ " and "High $\mathrm{CO}_{2}$ " vehicle per vehicle family and interpolation using those results.

Vehicle preparation and conditioning

$-23^{\circ} \mathrm{C}$ test and soak temperature. $\pm 3^{\circ} \mathrm{C}$ ( 5 min running average) during soak, $\pm 3^{\circ} \mathrm{C}$ at test start and $\pm 5^{\circ} \mathrm{C}$ during the test ( $2 \mathrm{~Hz}$ data)

- Electrical energy flow evaluated for the $12 \mathrm{~V}$ vehicle battery and correction of $\mathrm{CO}_{2} / \mathrm{FC}$ accordingly. For that reason, it is strictly forbidden to charge the battery before a type approval test.

Test and measurement procedure

- Bag analyzing sequence optimized (calibration and checks once per test run)

- PM/PN measurement using dilution tunnel, particulate filters and number measurement for gasoline engines as well,

- PM/PN Background correction (optional)

While the fundamental approach of using a chassis dynamometer and emissions sampling bags remains unchanged, all the updated and new elements of GTR15 have a substantial impact on laboratory design (see Fig. 9).

\subsection{Real driving Emissions (RDE)}

The term real driving emissions (RDE) has been deployed to refer to efforts to reduce the disconnect between laboratory testing (and results) and real world scenarios. A considerable body of evidence attests to the fact that laboratory test procedures, particularly type approval, represent a best- case scenario and that a range of emis- sions (including, perhaps most controversially, $\mathrm{CO}_{2} /$ fuel consumption) are considerably higher in real life than in laboratory tests. Equipment is now available to measure emissions in the field and this will soon be a legal requirement for passenger cars sold in the EU; the USA already has such requirements in place for heavy duty vehicles. However, much remains to be done to characterize the correlation between real world emissions and laboratory emissions [30]. Additionally, despite recent changes in the legislation, some details remain at least somewhat uncertain regarding $\mathrm{RDE}$ and $\mathrm{RDE}$ testing. RDE is intended to exist in parallel with WLTP legislation and measurements will be carried out in on-road driving with different conditions. Emissions which will be evaluated in RDE testing of $\mathrm{LDV}$ are: $\mathrm{NO}_{x}, \mathrm{CO}$ and $\mathrm{CO}_{2}$, later on also PN. It is scheduled to be introduced with Euro $6 \mathrm{c}$ and Euro $6 \mathrm{~d}$ limits. $\mathrm{CO}$ will be recorded and it may be subject to a limit at a later date [3, 19, 31].

To make an engine RDE-compliant can mean higher $\mathrm{CO}_{2}$ emissions (and thus higher FC). RDE standards are a challenge that requires the introduction of additional technologies [27].

The European commission has provided conformity factors for RDE tests. Throughout the normal life of a vehicle type approved according to [34], its emissions determined in accordance with the RDE requirements (Annex to the regulation) and emitted during any possible $\mathrm{RDE}$ test performed in accordance with the requirements 
of the Annex, shall not be higher than the following notto-exceed (NTE) values:

$$
\mathrm{NTE}_{\text {pollutant }}=\mathrm{CF}_{\text {pollutant }} \times \mathrm{TF}(\mathrm{p} 1, \ldots, \mathrm{pn}) \times \mathrm{EURO}-6
$$

The temporary $\mathrm{RDE}$ conformity factor $\mathrm{CF}$ for $\mathrm{NO}_{\mathrm{x}}$ emissions may equal 2.1 from 2017. The final CF effective from 2020 (Euro 6d) in the EU represents very stringent limits 1.5, because the 0.5 margin is close to the accuracy of current PEMS test equipment, but it will be implemented to satisfy boundary conditions $[26,27]$.

According to vehicle manufacturers, the $\mathrm{NO}_{\mathrm{x}} \mathrm{CF}$ should not be lower than 3 , to satisfy all boundary conditions such as varying temperature, wind, humidity and driving behaviour. It is worth noting that the RDE test procedure does not correct for ambient humidity (in contrast to laboratory emissions measurements).

Table 1. Conformity factor CF pollutant for the respective pollutant

\begin{tabular}{|l|c|c|}
\hline Pollutant & $\begin{array}{c}\text { Mass of oxides of nitrogen } \\
\left(\mathrm{NO}_{\mathrm{x}}\right)\end{array}$ & $\begin{array}{c}\text { Number of particles } \\
(\mathrm{PN})\end{array}$ \\
\hline CF pollutant & $1+$ margin*, with margin & to be confirmed... \\
& $=0.5$ upon request of the & latest proposal: \\
& manufacturer, the following & $1+$ margin, with \\
& temporary conformity & margin $=0.5$ \\
& factors may apply: 2.1 & \\
\hline
\end{tabular}

* "margin" is a parameter taking into account the additional measurement uncertainties introduced by the PEMS

The main differences between both test methods introduced are following $[9,12,19,23]$ :

WLTC:

- Realized on the conditioned chassis test stand $\rightarrow$ relatively better repeatability

- Less dependent on external factors

- Customized gearshifts - good flexibility

- Commences from cold start

RDE:

- Emissions related with real-life conditions

- Road profile, road surface quality, actual ambient conditions, traffic congestions and driver's behaviour (ecodriving, neutral, aggressive) determine final parameters of the test (constant speeds, acceleration rates) and final emission levels

- Relatively worse repeatability

- Ideal flexibility (usage of all gears)

- Complex procedure of data acquisition and its final validation and post-processing

- Cold start excluded (although this exclusion is under discussion and cold (and even hot) starts will likely be included in future) [13].

Under discussion and investigation by the EU's Joint Research Center (JRC) is also introducing rules for RDE testing of hybrid vehicles $[14,19]$.

Following the $1^{\text {st }}$ and $2^{\text {nd }}$ packages, at least two further packages will be voted on and eventually adopted in EU countries

\section{$3^{\text {rd }}$ package:}

Conformity Factor for Particle Number (PN) on-road emissions [18],

real-driving emissions after engine start (“cold-start RDE") [13],

RDE testing procedure for hybrid and light commercial vehicles [14],

Ki values for regenerating systems,

Others: consideration of the volatility of gasoline fuel on PN/ consideration of LD Commercial Vehicles / consideration of Small Volume Manufacturers and Ultra-Small Volume Manufacturers / requirements to publish the RDE CFs in the certificate of conformity

\section{$4^{\text {th }}$ package:}

In-service-conformity tests,

Some other issues raised over the past few months

Future steps

2016-2017: Reviewing RDE procedure and adapting provisions to ensure practicality and effective emissions testing [19]

\section{Particulate emissions - focus on the DI SI (gasoline) issue}

As a combustion-propelled mechanical system with many moving parts, of mass of at least $1000 \mathrm{~kg}$, moving over suboptimal terrain at speeds of up to around 40-50 meters per second, particulate emissions from vehicles are an inevitability - and not only from the engine (Fig. 10). The issue of nanoparticle emissions from internal combustion engines has evolved greatly over the years - both in terms of the emissions levels (which have now been reduced by orders of magnitude in many cases) and the scope of interest (no longer limited to Diesel engines). Concurrently, new test methods have been devised and a large body of toxicological evidence has been accumulated on the impact of such emissions. Legislation has evolved significantly in response to changes in technology and scientific information on the adverse effects of particulate; direct injection petrol engines are now a the focus of upcoming changes in European legislation (Table 2). Now that DPFs have made emissions from CI engines so low, it is natural that attention turns to other sources of particulate. SI engines remain the most widely used engine type for LD vehicles and more and more SI engines feature direct injection. The market share of direct injection SI engines (DISI) has grown rapidly; in the 2011 the new vehicle market share for the EU was $20 \%$ and $15 \%$ for the USA and has since grown further.

Advantages of DISI engines over PFI engines include:

- Potential for improved fuel efficiency,

- Better control over the injection process and fuel dosing,

- Certain emissions benefits, for example during start-up.

Disadvantages of DISI engines include:

- Emissions of particulate matter, which are generally much greater than from PFI engines (Fig. 11) 


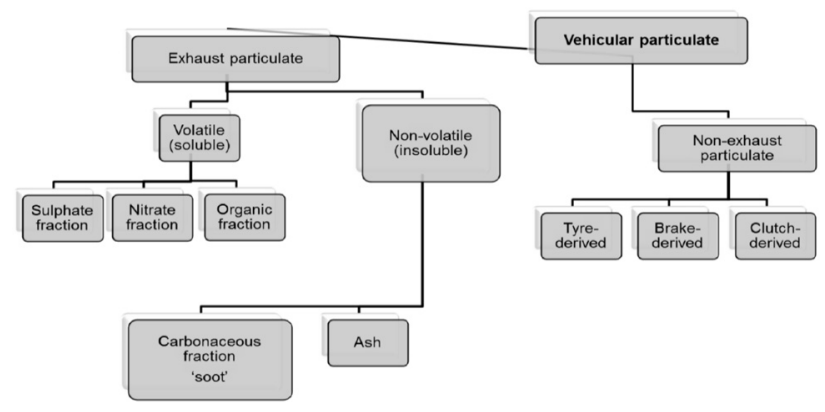

Fig. 10. The range of particulate emitted by a vehicle with an ICE

The causes of higher particulate matter emissions from DISI engines [2, 6, 7, 21, 24]:

- Slow burning pool fires formed on the wetted cylinder head and wall

- Imperfections in the injection spray cone

- Complex gasoline volatility effects

- Liquid fuel impingement on cold surface of the combustion chamber and pistons [2] - much worse at low ambient temperatures (Fig. 13) [6].

Table 2. Global limits for exhaust emissions of particulates from LDV and $\mathrm{PC}$

\begin{tabular}{|l|c|c|c|}
\hline $\begin{array}{l}\text { Jurisdiction / legislative } \\
\text { stage }\end{array}$ & $\begin{array}{c}\text { PM } \\
{[\mathrm{mg} / \mathrm{km}]^{*}}\end{array}$ & $\begin{array}{c}\text { PN } \\
{[\# / \mathrm{km}]}\end{array}$ & $\begin{array}{c}\text { Applicable } \\
\text { test cycle }\end{array}$ \\
\hline EU / Euro 5a & 5.0 & - & NEDC \\
\hline EU / Euro 5b & 4.5 & $6.0 \times 10^{11}$ & NEDC \\
\hline EU / Euro 6b & 4.5 & $\begin{array}{c}6.0 \times 10^{11} \\
6.0 \times 10^{12}\end{array}$ & NEDC \\
\hline EU / Euro 6c & 4.5 & $6.0 \times 10^{11}$ & NEDC/ \\
\hline WLTC & & & \\
\hline EU / Euro 6d & 4.5 & $6.0 \times 10^{11}$ & WLTC \\
\hline $\begin{array}{l}\text { EPA / Tier II (“full useful } \\
\text { life", 8 bins) }\end{array}$ & $0.0-12.43$ & None & FTP-75 \\
\hline $\begin{array}{l}\text { EPA / Tier II ("full useful } \\
\text { life") }\end{array}$ & 1.86 & None & FTP-75 \\
\hline $\begin{array}{l}\text { CARB / Exhaust Mass Emis- } \\
\text { sion Standards (2015) }\end{array}$ & 6.21 & None & FTP-75 \\
\hline $\begin{array}{l}\text { CARB / Particulate Stan- } \\
\text { dards (2017) }\end{array}$ & 1.86 & None & FTP-75 \\
\hline $\begin{array}{l}\text { CARB / Particulate Stan- } \\
\text { dards (2028) }\end{array}$ & 0.62 & $\begin{array}{c}\text { Will be } \\
\text { included }\end{array}$ & FTP-75 \\
\hline Japan / Post New Long Term & 5.0 & None? & JC08 \\
\hline China / CN6a (2019) & 4.5 & $6.0 \times 10^{11}$ & WLTP \\
\hline China / CN6b (2022) & 3.0 & $6.0 \times 10^{11}$ & WLTP \\
\hline
\end{tabular}

Despite conceptual similarities to the Diesel engine, engine out emissions from DISI engines are normally 1-2 orders of magnitude below engine out emissions from CI engines; significant numbers of particles are below $20 \mathrm{~nm}$ in terms of their electrical mobility diameter (Fig. 12) [7, 8, 24].

The EU, EPA, CARB and Japan have set limits for solid emissions from vehicles featuring DISI engines (albeit not always technology-specific).

The limits are connected with mass emissions of PM. PN so far only targeted in EU legislation.
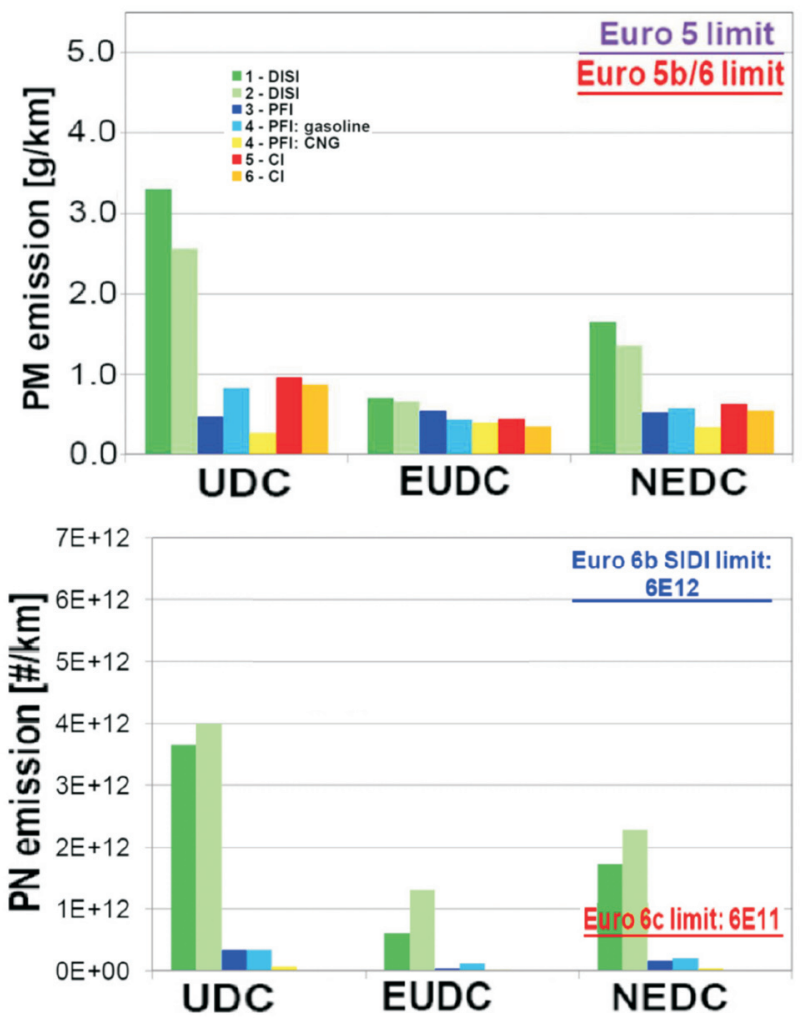

Fig. 11. PM and PN emissions from a range of vehicles, including two SIDI vehicles [7]



Fig. 12 Size distribution of particles emitted by a direct injection petrol vehicle

Another important issue discussed at the UNECE GRPE sessions and other forums is introduction of measurement of sub $23 \mathrm{~nm}$ particles currently not measured according to the PMP procedure (Fig. 12) [29].

There are some potential issues connected with measurement of particles in exhaust gas, the most important of which are:

- Particle number (PN) measurements during regeneration phases,

- Measurements of sub $23 \mathrm{~nm}$ particles especially in the context of the incoming WLTP cycle and DISI engines equipped with GPFs (see Fig. 11),

- Further improvements to the calibration procedure: 
- $\quad$ existing systems with small modification can measure below $23 \mathrm{~nm}$,

- however, below $10 \mathrm{~nm}$ the measurements will have high uncertainty,

- for $>10 \mathrm{~nm}$ measurements small differences can exist (e.g. at cold start),

- including information on the size distribution,

- PN counting from raw exhaust via fixed dilution

- Interest in this approach confirmed by some engine manufacturers and some instrument manufacturers

- The 01 Series of amendments to Reg. 132 already includes such a possibility but the procedure has not been defined

- Viability of the filter method for measuring extremely low emissions (cf. CARB LEV III $1 \mathrm{mg} / \mathrm{mile}$ ).
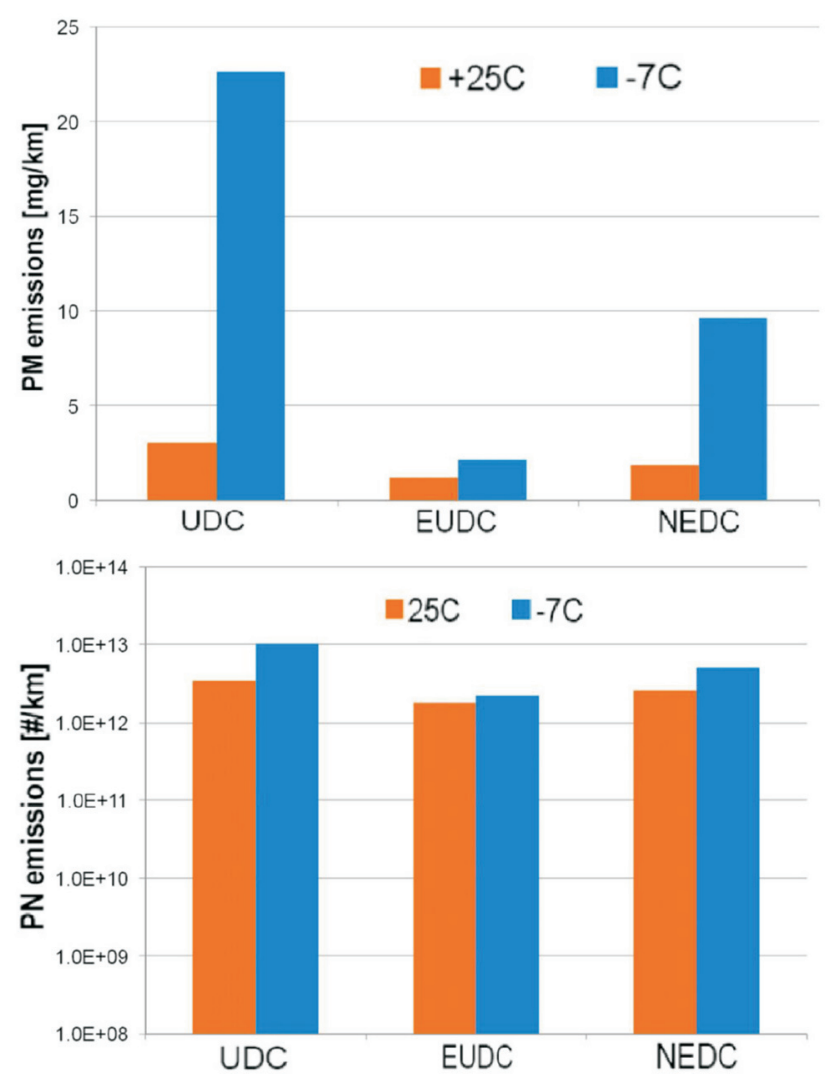

Fig. 13. PM and PN emissions from a SIDI vehicle tested at two ambient temperatures [7]

\section{5. $\mathrm{CO}_{2}$ emissions reduction}

Greenhouse gas emissions have become a real issue. New passenger cars sold in 2015 emitted (over the NEDC)

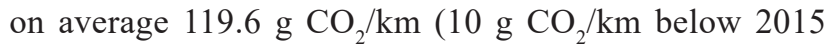
target). 13.7 million new cars were registered in $2015-\mathrm{a}$ $9 \%$ increase in comparison to 2014 . The EU wants to limit $\mathrm{CO}_{2}$ to $95 \mathrm{~g} \mathrm{CO} / \mathrm{km}$ in 2021. The Global Fuel Economy Initiative (GFEI) " 50 by 50 " is an initiative jointly launched by UNEP (UN Environment Program), IEA (International Energy Agency), ITS (International Transport Forum), FIA Foundation. It calls for cars worldwide to be made $50 \%$ more fuel efficient by 2050, along with interim targets [10]. In Europe even full transport decarbonisation in the EU by
2050 is also under discussion, and exporting that technology to other large emitters [22].

Current official EU rules for $\mathrm{CO}_{2}$ limitation are following:

- EC 443/2009 regulates the average specific emission of $\mathrm{CO}_{2}$ for each manufacturer for NPC registered in EU in each CY

- Permitted $\mathrm{CO}_{2}$ emissions $=130 \mathrm{~g} / \mathrm{km}[\mathrm{NEDC}]+0.0457$

* (vehicle mass [kg] - 1,372 [kg])

- 2020 target $95 \mathrm{~g} \mathrm{CO}_{2} / \mathrm{km}$ in 2021 - application of WLTP after 2017

Official US rules:

-2 sets of parallel standards, namely:

- CAFE - Corporate average standards adopted by NHTSA

- GHG - Green House Gas standards adopted by EPA

- MY 2022 - 25 Mild Term Evaluation (MTE) made by EPA. The MTE will commence in early 2016 and issued a final determination by April 2018 with final standards to follow.

- EPA and CARB GHG regulations are harmonized from 2017-2025.

- Other countries with $\mathrm{CO}_{2}$ (or fuel economy) limitations: Japan, Brazil, PR of China, South Korea, Taiwan.

Diesel cars sold in the EU are still in the majority (52\% of total sales), but this share has shown a tendency to decline this year. The average $\mathrm{CO}_{2}$ emissions intensity (over the NEDC) in 2015 was [33]:

- petrol fuelled cars: $122.6 \mathrm{CO}_{2} / \mathrm{km}$

- Diesel fuelled cars: $119.2 \mathrm{~g} \mathrm{CO}_{2} / \mathrm{km}$.

Hybrids and battery-electric vehicles (178 100 cars) constituting $1.3 \%$ of total sales 57000 pure battery-electric vehicles were registered - a $50 \%$ increase in comparison to 2014 [33].

\section{Engine technology and aftertreatment systems developments trends}

\subsection{Engine technology trends}

It has been confirmed by many experts from the EU, USA and Asia that internal combustion engines (ICEs) remain the main solution for transportation needs (especially for LDV); considerable progress has been made in reducing emissions and fuel consumption, but these goals need to be harmonised and pursued simultaneously, with "engine + aftertreatment + fuel + lubricant" considered as a single system, along with all interactions between elements of this system. [9, 16, 17, 26]. Light duty and Heavy duty engine and emissions control technologies continue to evolve at a fast pace, showing market improvements in engine efficiency. LD gasoline engine concepts are achieving 45\% BTE (Brake Thermal Efficiency) and closing the gap to Diesel engines. Current HD diesel engines are currently already demonstrating 50\% brake thermal efficiency (BTE) and proposals have been developed to reach up to $55 \%$ BTE $[20,26]$.

Changes in world-wide emissions regulations, especially the introduction of WLTP and RDE, first in the EU, perhaps later also in other continents, will lead to major changes in 


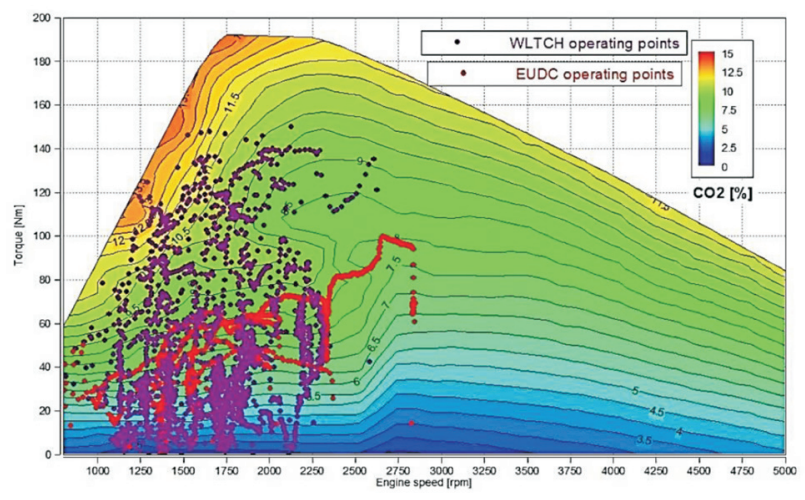

Fig. 14. $\mathrm{CO}_{2}$ emissions measurements under the GTR 15 regime: NEDC vs WLTC

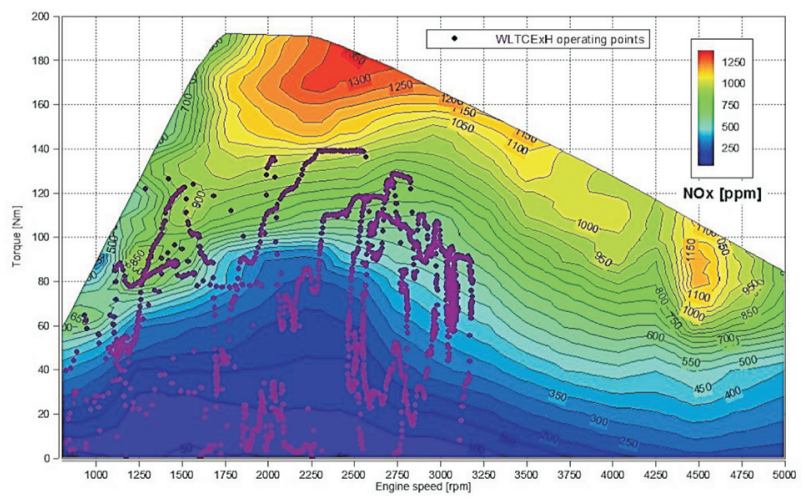

Fig. 15. $\mathrm{NO}_{\mathrm{x}}[\mathrm{ppm}]$ emission measured during engine map on the engine test bench with indicated WLTC operating points



Fig. 16. Smoke [FSN] emission measured during engine map on the engine test bench with indicated NEDC operating points

engine technology, control strategy and calibration. The test cycle is an important change (particularly given the differences between the WLTC and the NEDC), but the test cycle is only part of the story. More important are changes in testing conditions, especially road load simulation, inertia setting, etc. (Figs 14-16).

But the new RDE test method introduction scheduled from 2017 will have an even higher influence on engine technology and sizing. The trend for the past few years has been one of downsizing (reduction of engine displacement, number of cylinders, dimensions and overall weight), as a consequence of $\mathrm{CO}_{2}$ reduction trend is introduced in a synergy of many other technologies, such as: direct injection technology for both CI and SI engines, modulation of the compression ratio (variable $\mathrm{CR}$ ), boosting technology - mainly 1-or 2-stage turbocharging, optimization of the engine's controlling algorithm by adding many new parameters that influence the calibration, valve actuation technology, special dedicated exhaust aftertreatment systems as a combination of multiple different catalysts/traps or specially catalysed filters like SDPFs. (Fig. 17).

However, small, downsized European Diesel engines, when driven at higher loads than current tests require (Fig. 15), exceed permitted levels of $\mathrm{NO}_{x}$ emissions, mainly due to the higher combustion temperatures generated by turbocharging. In the case of downsized gasoline engines (especially DI versions) fuel efficiency is much lower and particulates emissions become higher.

However, today engine manufacturers have to switch back to bigger engines - i.e. to upsize their engines again and to move from engine downsizing to engine rightsizing (in effect increasing the engine displacement and sometimes the number of cylinders) in order to be able to meet RDE requirements with low CFs - particularly for $\mathrm{NO}_{x}$ (Figs 14-16).

The new, wider areas of the engine map which must be optimised concerning the emission of regulated pollutants are a very important factor in powertrain design, as shown in Figs 17-18.

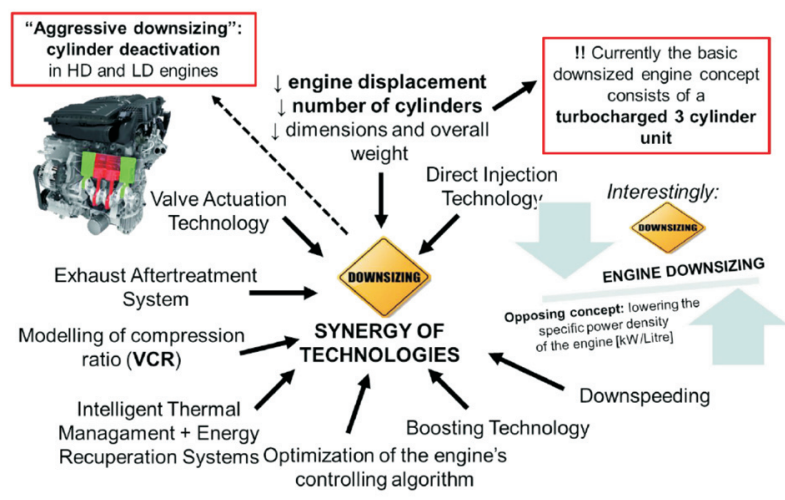

Fig. 17. Engine technology trends - a summary of the past few years

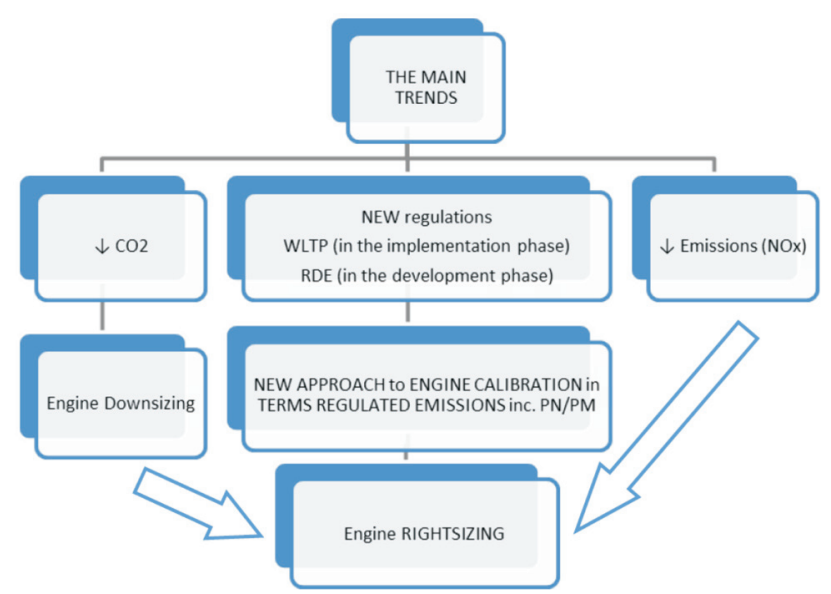

Fig. 18. Engine technology trends - the new tendency: rightsizing 


\subsection{Aftertreatment systems for CI and SI DI engines}

Over the last decade exhaust aftertreatment systems of CI engines used in LD and HD vehicle applications have been developed significantly. Diesel engines feature a close coupled oxidation catalyst (DOC) for conversion of $\mathrm{HC}$ and $\mathrm{CO} \&$ diesel particulate filter (DPF) to reduce particulate mass and number, in conjunction with Selective Catalytic Reduction (SCR) for $\mathrm{NO}_{\mathrm{x}}$ reduction. Alternatively, CI engines can be found with close coupled Lean $\mathrm{NO}_{x}$ Trap (LNT - sometimes also called an NSC - nitrogen storage catalyst), with the functionality of an oxidation catalyst (DOC), and $\mathrm{NO}_{\mathrm{x}}$ trap. The first system (SCR) was mainly used in high displacement LD engines $>3.0 \mathrm{dm}^{3}$, while the second (LNT) can be seen in smaller diesel LD engines. Vehicle weight can be used as the criterion for choosing which type of DeNOx strategy is appropriate (Fig. 19).

SCR is preferred for HD vehicles because of its weight and volume. $\{\mathrm{DOC}+\mathrm{DPF}+\mathrm{SCR}+\mathrm{CUC}\}$ is quite large (its size is $850 \times 700 \times 700 \mathrm{~mm}$ for a $400 \mathrm{~kW}$ engine) but it's able to meet $\mathrm{CF}=1.5$. Another reason why it is used in $\mathrm{HD}$ vehicles is different type of driving in comparison to LD vehicles. HD vehicles undergo fewer cold starts and their engines are often used under steady state conditions with predictable load.

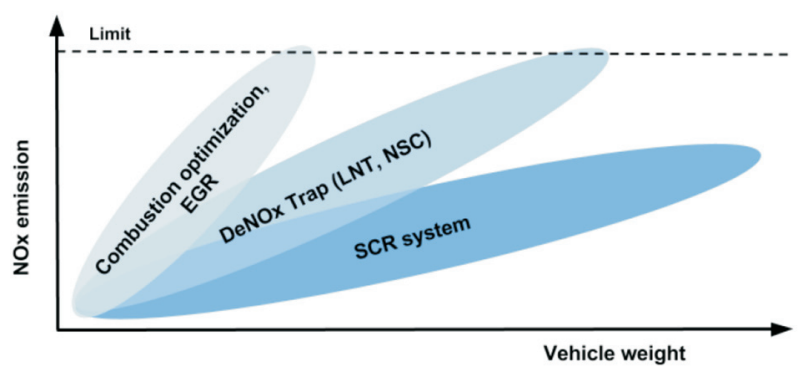

Fig. 19. Exhaust aftertreatment strategies for CI engines

After the introduction of the new WLTP procedure that will be introduced in 2017 and new RDE on-road emissions procedure in a similar time-frame to ensure that real-world emissions will be aligned with laboratory performance and emission of vehicle emissions legislation become again a critical driver for emissions control technology for LD vehicles.

The low conformity factors (CF) for LD vehicles, now confirmed $\left(\mathrm{NO}_{x}\right)$ or drafted $(\mathrm{PN})$, will certainly exert pressure on engine aftertreatment technologies both in LD and HD engines. Relatively low or very low CFs will cause substantial changes in technology. SCR or SDPF has to be used in all LDV powered by diesel engines to meet Euro 6c or Euro $6 \mathrm{~d}$ standards. ATS solutions would need to be "combined" in configurations, as follows (Fig. 20):

$-\{\mathrm{DOC}+\mathrm{DPF}+\mathrm{SCR}$ (mandatory) $\}$

$-\{\mathrm{DOC}+\mathrm{SDPF}+\mathrm{SCR}\}$

$-\{\mathrm{LNT}+\mathrm{DOC}+\mathrm{SDPF}\}$, for smaller LDVs with CI engines
As a consequence, there would be:

- more ATS systems,

- larger ATS components,

- greater AdBlue consumption,

- possibly greater fuel consumption $/ \mathrm{CO}_{2}$ emissions.

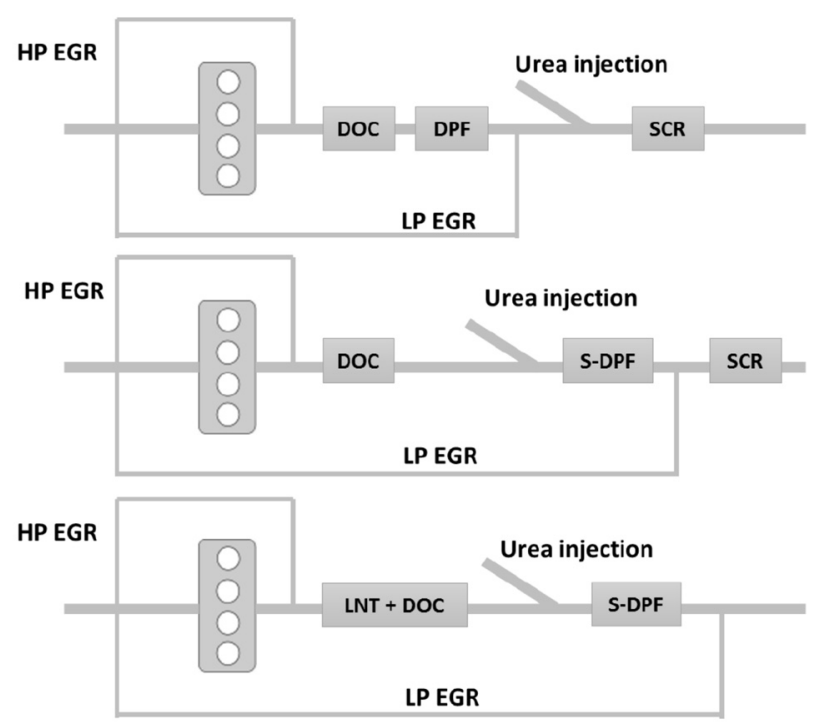

Fig. 20. Emission control technologies for LDV TDI to meet RDE $\mathrm{NO}_{\mathrm{x}}$ limits (source: AECC, 2016)

In the case of gasoline engines (SI) in LDV the main catalyst technology used to emissions control is the ThreeWay Catalyst (TWC) that operates in a closed-loop system including a lambda or oxygen sensor to control the air-tofuel ratio in the SI engine. TWCs are an efficient solution for gasoline port fuel injection engines (PFI), but in the case of direct-injection engines (DI), which are promoted in the EU due to their better fuel efficiency, this solution can't be sufficient to meet new Euro $6 \mathrm{c}$ PN limit of $6 \times 10^{11} \# / \mathrm{km}$. For SI DI engines ATS solutions would need to be "combined" in configurations, as follows:

- $\{\mathrm{TWC}+\mathrm{GPF}\}$ for SIDI stoichiometric engines,

$-\{\mathrm{TWC}+\mathrm{LNT}+\mathrm{GPF}\}$ for SIDI lean burn engines.

A few vehicle OEMs in Europe have already announced that all SIDI LDVs produced from 2017 will be equipped with GPF filter. Among them are: VW, Mercedes and Renault.

\section{Engine fuel and oil development}

Since fuel and lubricants are of vital importance - to the point where they can be considered to be powertrain components - R\&D work on fuels and lubricants has become arguably as important as research on engine hardware, etc. As well as technical and engineering requirements, there is strong pressure to switch to fuels which are cleaner and more sustainable in terms of life-cycle emissions. The most obvious candidates in this area are natural gas [4] and biofuels - one of the main trends for both petrol and Diesel is an increasing proportion of biofuels blended into the mix in many jurisdictions - ethanol in the case of petrol and FAME in the case of Diesel, although other options 
exist. Obviously, the function to be played by lubricants is that of reducing friction and avoiding engine damage, with additional obligations in terms of heat transfer and the removal of deposits, in some cases. All three of these roles can have an influence on fuel consumption. There is a delicate balance to maintain regarding keeping friction low while ensuring long-term durability and engine performance. Finally, lubricants must also be compatible with the vehicle's aftertreatment system.

In 2015 a new fuel-related initiative was announced in the USA, called the 'Co-Optima' programme [15]. This Co-Optimization initiative aims to simultaneously transform both transportation fuels and vehicles and their powertrains in order to maximize performance and energy efficiency, minimize environmental impact, and introduce the adoption of innovative combustion strategies in IC engines [32]. One of the important targets is to develop higher octane gasoline (e.g. $100 \mathrm{RON}$ ) that facilitates better engine efficiency [26].

\section{Summary}

As a result of the topics explored in the preceding sections of this paper, certain conclusions can be drawn, bearing in mind that the currently situation is highly dynamic and that the pace of change is very fast.

In view of the fact that both the WLTP and RDE testing will be introduced in the EU it is prudent to ask whether they will have the desired effect: a measurable impact on air quality. Given that the changes will apply only to new registrations, it is to be expected that there will be some considerable temporal lag in terms of the impact of RDE-compliant vehicles on air quality. On the subject of RDE-complaint vehicles, there are good reasons to believe that the required changes could increase $\mathrm{CO}_{2} / \mathrm{FC}$ and thus it there could be a situation in which the EU might have to moderate its expectations in terms of reduced $\mathrm{CO}_{2} / \mathrm{FC}$ in light of more stringent emissions requirements. In the USA, the recent trend has been towards zero emissions, with $\mathrm{CO}_{2} / \mathrm{FC}$ a lesser priority. Whether this trend continues, or whether $\mathrm{CO}_{2} / \mathrm{FC}$ will become more important, remains to be seen. Regarding emissions limits in general, limits are now so low (particularly US limits: LEV/ Tier III), that the physical lower limits for emissions from conventional combustion engines are being approached; the accuracy of the measurement technique has a progressively greater impact on progressively lower emissions. This leads to two closely related questions: will emissions limits go any lower? and can emissions limits go any lower?

The same applies to gravimetric particulate matter emissions limits - modern emissions levels are low and legal limits are also low - the sensitivity of the technique is questionable at these levels and PM testing is now effectively a pass/fail type test. Particle number (PN) has higher resolution and is a more effective tool for legislators, but at present this test is only carried out on vehicles with direct injection engines. Leading the way, China plans to mandate this type of test (and limit) for all vehicles apart from those running on $\mathrm{CNG}$ - this approach is ahead of the EU and the US and it remains to be seen how widely
PN limits will be applied internationally over the coming years. Given that exhaust particulate emissions are now so low (at least by mass), surely it is pertinent to pay close attention to vehicular non-exhaust particulate emissions (which are of a similar order of magnitude to exhaust particulate emissions).

While at present no $\mathrm{CF}$ has been proposed for $\mathrm{FC}$, this topic is of great interest to consumers. RDE testing includes requirements to monitor $\mathrm{CO}_{2}$ and the ubiquity of the internet means that such data will probably find their way into the public sphere. However, consumers may still treat such data with suspicion, and yet the results of RDE testing could affect buying habits and thereby the engines offered in the EU (and even beyond).

Trends in engine offerings are not set in stone and manufacturers may change their strategies in light of the factors and pressures discussed above. Specifically, it is possible that some engine design trends from recent years will slow down, stop, or even reverse. For example, Dieselisation (especially for small PC) in the EU and in the US (where the share is currently very low). Downsizing and turbocharging (at least the more aggressive types of turbocharging) may become a less attractive option, especially in view of the fact that downsized turbocharged engines tend to produce more $\mathrm{NO}_{\mathrm{x}}$ and that their $\mathrm{FC}$ benefits are often lower in RDE testing than over the NEDC. It is noteworthy that in the EU emissions limits themselves are not changing - rather, the conditions under which those limits must be met are being broadened - and therein lies the challenge for engine designers and powertrain engineers. Changes in global emissions regulations, focusing currently mainly in Europe more on $\mathrm{NO}_{\mathrm{x}}$ and $\mathrm{PN}$ emissions than on $\mathrm{CO}_{2}$ (as was the case in previous years), have a great influence on engine size and technology. Automotive OEMs have to move from "downsizing" engine concepts - which are good for low $\mathrm{CO}_{2}$ emissions, but very problematic for $\mathrm{NO}_{\mathrm{x}}$ emissions, not only for Diesels but also for GDI engines - to a new "rightsizing" concept that should give further consideration to the difficult $\mathrm{NO}$ - $\mathrm{PN}-\mathrm{CO}_{2}$ trade-off (amongst other factors). The next few years should bring some new "rightsized" engine families to the market, perhaps first in Europe, but later on also in Asia and the USA. This diametrically opposing strategy appears to be a good technical solution, but the marketability and attractiveness of such engine offerings may not be a simple task.

In an era of globalisation, transnational vehicle manufacturers and increasing integration of markets, it is perhaps surprising that there are so many differences between exhaust emissions legislation in different jurisdictions. The EU has already harmonised the requirements of all 28 member states, but one day harmonisation between the EU, US and even Japan may be possible.

This paper has focused mainly on engine and aftertreatment hardware, but the ultimate source of energy (fuel) is also important. Alternative fuels aside, it may be possible to radically decrease $\mathrm{CO}_{2}$ emissions and $\mathrm{FC}$ by improving "conventional" fuel types - $100 \mathrm{RON}$ fuel is a promising 
direction and something vehicle manufacturers would like to see, but global availability remains a distant goal.

While the subject matter of this area of discussion is of a technical/engineering nature, the dimensions of the argument extend well beyond the technical arena: legislation is changing (and has already changed); rapid changes in the strategies pursued by vehicle and engine manufacturers could have significant socioeconomic impacts; buying habits and whether consumers can be persuaded to upgrade to new, fuel efficient vehicles are naturally of economic importance. Finally, there is the raison d'etre of the entire topic: the environment, specifically urban air quality and anthropogenic greenhouse emissions.

\section{Abbreviations}

$\begin{array}{ll}\text { ATS } & \text { Aftertreatment system } \\ \text { BS } & \text { Bharat Stage } \\ \text { CAFE } & \text { Corporate Average Fuel Economy } \\ \text { CARB } & \text { California Air Resources Board } \\ \text { CF } & \text { Conformity Factor } \\ \text { CRF } & \text { Code of Federal Regulations } \\ \text { CI } & \text { Compression Ignition engine } \\ \text { CNG } & \text { Compressed Natural gas } \\ \text { CUC } & \text { Clean Up Catalyst } \\ \text { DI engines } & \text { Direct Injection engines } \\ \text { DISI } & \text { Direct Injection Spark Ignition engines } \\ \text { DOC } & \text { Diesel Oxidation Catalyst } \\ \text { DPF } & \text { Diesel Particulate Filter } \\ \text { EPA } & \text { Environment Protection Agency } \\ \text { FAME } & \text { Fatty Acid Methyl Ester } \\ \text { FC } & \text { Fuel Consumption } \\ \text { FIA Foundation } & \text { Fédération Internationale de l'Automobile Foun- } \\ & \text { dation } \\ \text { FRM } & \text { Final Rule Making (USA) } \\ \text { GDI } & \text { Gasoline Direct Injection engine } \\ \text { GFEI } & \text { Global Fuel Economy Initiative } \\ \text { GHG } & \text { Greenhouse Gas } \\ \text { GTR15 } & \text { Global Technical Regulation No. 15 } \\ \text { HDV } & \text { Heavy Duty Vehicles } \\ \text { ICEs } & \text { Internal Combustion Engines } \\ \text { IEA } & \text { International Energy Agency } \\ \text { ITS } & \text { International Transport Forum } \\ \text { JC } & \text { Japanese test Cycle } \\ \text { LDVs } & \text { Light Duty Vehicles } \\ \text { LNT } & \text { Lean NOx Trap } \\ \text { MAC } & \text { Mobile Air-Conditioning } \\ \text { MTE } & \text { Midterm Evaluation (USA) } \\ & \end{array}$

$\begin{array}{ll}\text { MY } & \text { Model Year (USA) } \\ \text { NEDC } & \text { New European Driving Cycle } \\ \text { NHTSA } & \text { National Highway Traffic Safety Administration } \\ \text { NMOG } & \text { Non-Methane Organic Gases } \\ \text { NPC } & \text { National Population Commission } \\ \text { NSC } & \text { Nitrogen Storage Catalyst } \\ \text { NTE limits } & \text { Not-To-Exceed limits } \\ \text { OBD } & \text { On-Board Diagnostics } \\ \text { OEMs } & \text { Original Equipment Manufacturers } \\ \text { PEMS } & \text { Portable Emissions Measurement System } \\ \text { PFI } & \text { Port Fuel Injection engines } \\ \text { PM } & \text { Particulate Mass } \\ \text { PMP } & \text { Particulate Measurement Programme } \\ \text { PN } & \text { Particulate Number } \\ \text { R\&D } & \text { Research and Development } \\ \text { RDE } & \text { Real Driving Emissions } \\ \text { RON } & \text { Research Octane Number } \\ \text { SCR } & \text { Selective Catalytic Reduction } \\ \text { SDPFs } & \text { DPFs with SCR coating } \\ \text { SI } & \text { Spark Ignition engine } \\ \text { TWC } & \text { Three-Way Catalyst } \\ \text { UN ECE GRPE } & \text { the Working Party on Pollution and Energy of Uni- } \\ & \text { ted Nations Economic Commission for Europe } \\ \text { UNEP } & \text { United Nations Environment Program } \\ \text { US FTP-75 } & \text { United States Federal Test Procedure } \\ \text { WLTC } & \text { Worldwide harmonized Light vehicles Test Cycle } \\ \text { WLTP } & \text { Worldwide harmonized Light vehicles Test Pro- } \\ & \text { cedures } \\ \text { WLTP-DHC } & \text { Informal Subgroup on the Development of the } \\ \text { WLTP-DTP } & \text { WLTP Test Cycle } \\ & \text { Informal Subgroup on the Development of the } \\ & \text { WLTP Test Procedure } \\ & \end{array}$

\section{References}

[1] AVL Emissions Testing Handbook - 2016.

[2] Badshah, H., Kittelson, D., Northrop W. Particle Emissions from Light-Duty Vehicles during Cold-Cold Start, SAE Int. J. Engines 9(3):2016, doi:10.4271/2016-01-0997.

[3] Badur, J., Kohler, F., Schmidt, H. Real Driving Emissions (RDE) - status of discussion and practical implementation. 37th International Vienna Motor Symposium 28-29 April 2016.

[4] Bielaczyc, P., Szczotka, A., Woodburn, J. Regulated and Unregulated Exhaust Emissions from CNG Fueled Vehicles in Light of Euro 6 Regulations and the New WLTP/ GTR 15 Test Procedure, SAE Int. J. Engines 8(3):2015, doi:10.4271/2015-01-1061.

[5] Bielaczyc, P., Woodburn, J., Szczotka, A. A Comparison of Carbon Dioxide Exhaust Emissions and Fuel Consumption for Vehicles Tested over the NEDC, FTP-75 and WLTC Chassis Dynamometer Test Cycles, SAE Technical Paper 2015-01-1065, 2015, doi:10.4271/2015-01-1065.

[6] Bielaczyc, P., Woodburn, J., Szczotka, A. Investigations into Particulate Emissions from Euro 5 Passenger Cars with DISI Engines Tested at Multiple Ambient Temperatures, SAE Technical Paper 2015-24-2517, 2015, doi:10.4271/2015-242517.

[7] Bielaczyc, P., Woodburn, J., Szczotka, A. Particulate Emissions from European Vehicles Featuring Direct Injection Spark Ignition Engines Tested Under Laboratory 
Conditions, SAE Int. J. Fuels Lubr. 7(2):580-590, 2014, doi:10.4271/2014-01-1608

[8] Bielaczyc, P., Woodburn, J., Szczotka, A. Exhaust Emissions of Gaseous and Solid Pollutants Measured over the NEDC, FTP-75 and WLTC Chassis Dynamometer Driving Cycles, SAE Technical Paper 2016-01-1008, 2016, doi: 10.4271/2016-01-1008

[9] Bielaczyc, P. Which strategy is better for emissions control - the EU or the US?: and introduction to the question. CE-2016-301, Proceedings of the 5th International Exhaust Emissions Symposium 19-20 May 2016, BOSMAL, BielskoBiala (Poland), ISBN No. 978-83-931383-9-5.

[10] Cambridge Econometrics \& ICCT. Oil Market Futures - A report for the European Climate Foundation, April 2016.

[11] Delphi, Worldwide Emissions Standards Passenger Cars Light Duty 2016-2017

[12] Engeljehringer, K. Global emission regulations and testing methods on the local differences. CE-2016-304, Proceedings of the 5th International Exhaust Emissions Symposium 1920 May 2016, BOSMAL, Bielsko-Biala (Poland), ISBN No. 978-83-931383-9-5.

[13] European Commission, Joint Research Centre (JRC), IET - Institute for Energy and Transport Sustainable Transport Unit. RDE cold-start provisions - Contribution to the RDE working group, 18 May 2016.

[14] European Commission, Joint Research Centre (JRC), IET - Institute for Energy and Transport Sustainable Transport Unit. RDE testing of Hybrid Vehicles - Contribution to the RDE working group, 18 May 2016.

[15] Farrell, J. Optima Programme Overview. Optima Stakeholder Listening Day June 16, 2015, U.S Department of Energy.

[16] Fraidl, G. Impact of Extended Emission Compliance on Passenger Car Powertrain Technology Conference Proceedings of "CO2 reduction for Transportation System" June 29-30, Politecnico Torino, Italy.

[17] Franco, V., Muncrief, R., Mock, P., German, J. Vehicle emission standard design and enforcement approaches in the EU and US. CE-2016-302, Proceedings of the 5th International Exhaust Emissions Symposium 19-20 May 2016, BOSMAL, Bielsko-Biala (Poland), ISBN No. 978-83-931383-9-5.

[18] Giechaskiel, B., Riccobono, F., Weiss, M. Real-Driving Emissions (RDE) Update on Particle Number (PN) measurements with Portable Emission Measurement Systems (PEMS). 1 June 2016, Stuttgart (Germany).

[19] Hill, L. Real Driving Emissions for Light Duty Vehicle (RDE-LDV) Legislation \& OBS Update, 2016 Horiba Ltd (not published).

[20] Johnson, T. Vehicular Emissions in Review" SAE Int. J. Engines 9(2):1258-1275, 2016, doi:10.4271/2016-01-0919.

[21] Koczak, J., Boehman, A., Brusstar, M. Particulate Emissions in GDI Vehicle Transients: An Examination of FTP, HWFET, and US06 Measurements, SAE Technical Paper 2016-010992, 2016, doi:10.4271/2016-01-0992.

[22] Maggiore, M. Road Transport Decarbonisation in the European Research Perspective. Conference Proceedings of "CO2 reduction for Transportation System” June 29-30, Politecnico Torino, Italy

[23] Merkisz, J., Pielecha, J., Bielaczyc, P., Woodburn, J. Analysis of Emission Factors in RDE Tests As Well as in NEDC and WLTC Chassis Dynamometer Tests, SAE Technical Paper 2016-01-0980, 2016, doi:10.4271/2016-01-0980.

[24] Myung, C.L., Ko, A., Park, S. Review on characterization of nano-particle emissions and PM morphology from internal combustion engines: Part 1, Int.J Automot. Technol. (2014) 15: 203.

[25] Olechiw, M. USEPA Light-duty Greenhouse Gas Emission Programs and Midterm Evaluation. 37th International Vienna Motor Symposium 28-29 April 2016.

[26] Panel discussion "An executive view of powertrains powering the possibilities" on 13th April 2016 at the SAE 2016 World Congress and Exhibition, Detroit, USA.

[27] Samaras, Z. The World Harmonized Test Protocol: How will the new Regulation affect $\mathrm{CO} 2$ emissions from modern passenger cars? Conference Proceedings of " $\mathrm{CO} 2$ reduction for Transportation System" June 29-30 2016, Politecnico Torino, Italy.

[28] Steininger, N. World Light duty Test Procedures: Coming Closer to Reality. European Commission, DG Growth.

[29] Technical Expert Panel Discussion: "Sub-23 nm Particle Emissions from Engines (PFL499) on 14th April 2016 at the SAE 2016 World Congress and Exhibition, Detroit, USA.

[30] Technical Expert Panel Discussion: "What will be the Impact of PEMS Testing on Future Vehicle Emissions Regulations, Market and Technology?" on 13th April 2016 at the SAE 2016 World Congress and Exhibition, Detroit, USA.

[31] Vlachos, T. et al. The Euro 6 Real Driving Emissions (RDE) procedure for light-duty vehicles: Effectiveness and practical aspects. 37th International Vienna Motor Symposium 28-29 April 2016.

[32] Wallner, T. Fuel-Engine Co-Optimization. CE-2016-320, Proceedings of the 5th International Exhaust Emissions Symposium 19-20 May 2016, BOSMAL, Bielsko-Biala (Poland), ISBN No. 978-83-931383-9-5.

[33] Walsh, M. Car Lines 2016.

[34] Zhao, F. Latest Development of Automotive Emission Regulations in China at the Panel discussion: "The global emission standards experiment" on April 13, 2016 during SAE 2016 World Congress and Exhibition, Detroit, USA.

[35] www.eea.europa.eu - European Environment Agency.
Piotr Bielaczyc, DEng. - head of the Engine Research Department, BOSMAL Automotive Research and Development Institute Ltd in Bielsko-Biała.

e-mail:piotr.bielaczyc@bosmal.com.pl

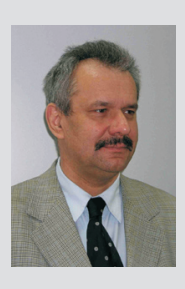

Joseph Woodburn, MSci. - researcher it the Engine Research Department, BOSMAL Automotive Research and Development Institute Ltd in Bielsko-Biała.

e-mail:joseph.woodburn@bosmal.com.pl

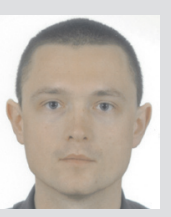

